\title{
Comparisons between long-term outcomes of the use of reposition flaps and replantations in fingertip amputations
}

\author{
당 Emin Sir, M.D., ${ }^{1}$ Alper Aksoy, M.D., ${ }^{2}$ @ Meliha Kasapoğlu Aksoy, M.D. ${ }^{3}$
}

\author{
${ }^{1}$ Department of Plastic, Reconstructive and Aesthetic Surgery, Private Practice, İmir-Turkey \\ ${ }^{2}$ Department of Plastic, Reconstructive and Aesthetic Surgery, Acıbadem Konur Surgical Center, Bursa-Turkey \\ ${ }^{3}$ Department of Physical Medicine and Rehabilitation, University of Health Sciences, Bursa Yüksek İhtisas Training and \\ Research Hospital, Bursa-Turkey
}

\begin{abstract}
BACKGROUND: Replantation is the gold standard procedure for traumatic amputation of fingertips. Reposition flap procedure is performed using nail-bone complex as a free graft and covering graft site with a flap to preserve original finger length, nail complex, and sensory functions of fingertip in pateints where microsurgical methods cannot be applied. In our study, we aimed to compare the long-term outcomes of patients with amputated fingertips who underwent replantation or reposition flap procedures.
\end{abstract}

METHODS: Thirty-five patients of replantation and 28 patients of reposition flap procedures only for $2^{\text {nd }}$, $3^{\text {rd }}$, and $4^{\text {th }}$ fingertip amputations were included in the study. Complete fingertip amputations involved Foucher zones 2 and 3 . The patients were followed up postoperatively for a median period of 13 months (9-23 months). All patients were assessed with static and dynamic 2-point discrimination tests, Semmes-Weinstein monofilament test, and cold intolerance test for the development of neuroma on the donor site.

RESULTS: In 5 patients, replantation procedure failed. In such failed patients, after the removal of necrotic tissues, the stump was either repaired or reconstruction with a flap was applied. Wound dehiscence was observed at the lateral sides of the flaps in 2 patients who underwent reposition procedures.

CONCLUSION: Reposition flap repair can be a good cost-effective alternative to other fingertip repair procedures in appropriately selected patients who are not amenable to microsurgery. It preserves the length and sensory functions of fingertips and enables patients to return to their daily life as soon as possible.

Keywords: Fingertip amputation; replantation; reposition flap; trauma.

\section{INTRODUCTION}

Traumatic fingertip amputation is the most common injury of the upper extremities. Treatment for fingertip amputation may vary from a simple debridment or secondary healing to replantation, which is a complicated procedure. No matter what type of surgical method is performed, the main goal is to have a fingertip that functions normally and is aesthetically acceptable. ${ }^{[1]}$ Recently, replantation has been considered as a gold standard. ${ }^{[2]}$ It improves the reconstruction of the missing part by using its original tissue. Minimizing donor site mor- bidity is another advantage of replantation. Replantation is technically difficult in amputations involved with distal to distal interphalangeal joint because of the small diameter of an artery and venous problems. Replantation may not be always applicable as it requires microsurgical experience and special surgical instruments. In addition, it is a costly and challenging operation. Improper replantation treatment could result in deformity, such as shortened fingertip, neuroma of the finger pulp, loss of nail complexity, and non-aesthetic appearance. ${ }^{[3]}$

Cite this article as: Sir E, Aksoy A, Kasapoğlu Aksoy M. Comparisons between long-term outcomes of the use of reposition flaps and replantations in fingertip amputations. Ulus Travma Acil Cerrahi Derg 2018;24:462-467.

Address for correspondence: Emin Sir, M.D.

Mimar Sinan Mahallesi, Ali Çetinkaya Bulvarı, No: 69, K: 3, D: 6, Alsancak, 35220 İzmir, Turkey

Tel: +90532 - $5898551 \quad$ E-mail: eminsir@gmail.com 
Reposition flap procedure is performed by using nail-bone complex as a free graft and covering graft site with a flap to preserve the original finger length, nail complex, and sensory functions of fingertip in patients where microsurgical methods cannot be applied. ${ }^{[4]}$ This method has been indicated to cause clubbed nails, ungual dystrophy, joint stiffness, and unsatisfactory finger length. ${ }^{[5]}$ Therefore, in our study, we aimed to compare the long-term results of the patients with amputated fingertips who underwent replantation or reposition flap procedures.

\section{MATERIALS AND METHODS}

\section{Study Design}

Between May 2010 and January 2013, 35 patients of replantation and 28 patients of reposition flap procedures only for 2nd, 3rd, and 4th fingertip amputations were included in the study. Replantations were performed for patients with guillotine amputations $(n=17)$, crush injuries $(n=12)$ and avulsions $(n=7)$. Reposition flap procedures were applied for patients with avulsion $(n=19)$ and crush type injuries $(n=9)$. Majority of the amputations were caused by accidents encountered at workplaces. Complete fingertip amputations involved Foucher zones 2 and 3. Average ischemia time was 3.5 (range, I-9) hours. All patients were operated under axillary block anesthesia.

\section{Surgical Technique For Replantations}

Bone stabilization was achieved using Kirschner wire without damaging the interphalangeal joint. Under microscopic visualization, central artery $(n=29)$ and lateral digital artery anastomoses $(n=6)$ were performed. In 4 patients who were not amenable for end-to-end anastomosis, vein grafts were used. Palmar vein anastomoses were performed in 25 patients. All anastomoses were performed using $10 / 0$ or $11 / 0$ nylon sutures. Nerve coaptation was performed in 23 patients. Average operative time was 90 (range, 80-120) minutes. The patients received I cc $5000 \mathrm{IU}$ heparin during operation and 100 $\mathrm{mg}$ acetylsalicylic acid for 30 days. Since vein repair was performed during replantation, no bleeding episode was encountered that obviated the need for blood transfusion. The patients were discharged after an average of 3 (range, 2-8) days.

\section{Surgical Technique For Reposition Flap}

Proximal segment was partially debrided before the application of the reposition flap. Skin of the distal segment was harvested as full-thickness skin graft; after removing all of the remaining soft tissues from operative site, a monocortical bone segment was constructed, and by using a $0.8 \mathrm{~mm}$ Kirschner wire bone-nail complex, it was fixed to the proximal segment. Nail beds were repaired with $6 / 0$ rapid vicryl sutures. In all patients, reverse homodigital flaps were harvested from the non-dominant site to cover the naked bone. After dissection of the artery and nerve, the proximal segment of the artery was ligated and the proximal end of the nerve was embedded in soft tissue. Following elevation of the flap, the nerve of the flap was coapted to the other digital nerve of the finger with an incision made on the appropriate site distal to the digital nerve, which was closed with 10/0 nylon sutures. Flap was sutured on the bone with $6 / 0$ prolene sutures. If it was applicable, then the flap donor sites were primarily closed. The skin of the amputed segment was used to prepare a full-thickness skin graft for donor site wounds, which were not suitable for primary closure (Fig. I). Average operative time was 60 (range, 50-90) minutes. Kirschner wires were removed after an average of 31.2 (range, 24-35) days, and the patients were then included in the rehabilitation program. The patients received an average of 29.4 (range, 28-33) sessions of rehabilitation.

\section{RESULTS}

In all patients, sensory functions, appearance, lengths of the fingers, nail structure, and new finger pulp were evaluated by the same person. The patients' period off work during the process was approximately 80.6 (range, 78-93) days in the replantation and 82.3 (range, 80-95) days in the flap reposition series. The patients were followed up for an average of I 3 (range, 9-23) months.

In 5 patients, replantation procedures failed. In these failed patients, after the removal of necrotic tissues, the stump was either repaired or reconstruction with a flap was applied. The lengths of replanted fingers were approximately 2.3 (range, 0-10) $\mathrm{mm}$ shorter than the corresponding finger of the contralateral hand. As for nail deformities, I patient
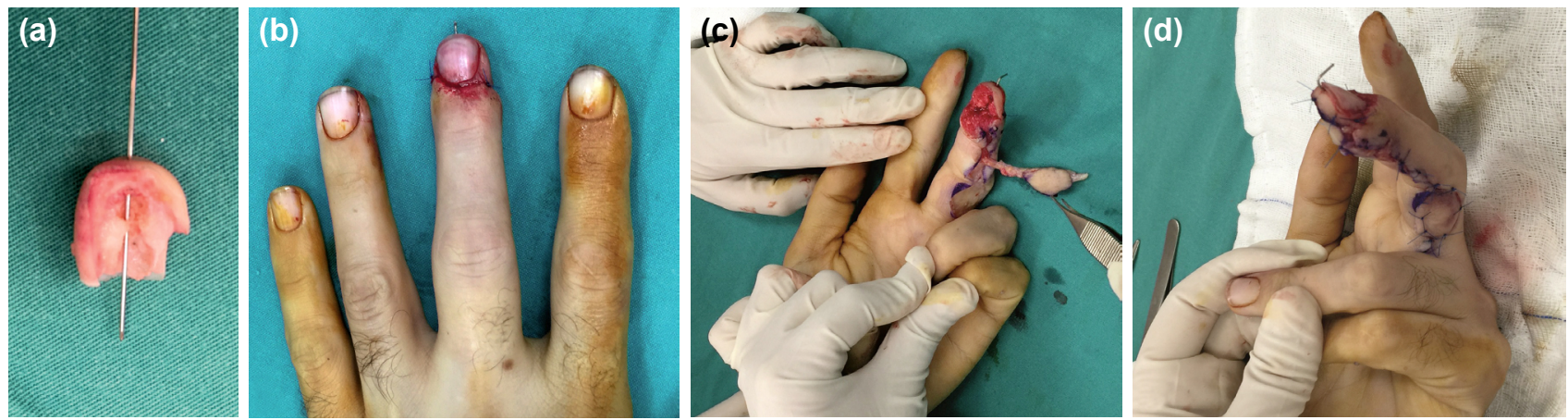

Figure 1. (a, b) Amputated part was prepared and fixed using Kirschner wire. (c) Flap was elevated. (d) Flap was sutured and donor area was closed using the skin of the amputated part. 
Table I. Comparison for replantation and reposition flap groups

\begin{tabular}{lcc}
\hline & Replantation group $(\mathbf{n}=\mathbf{3 5})$ & Reposition flap group $(\mathbf{n}=\mathbf{2 8})$ \\
\hline Age (years) [mean (range)] & $38.2(18-52)$ & $39.8(18-57)$ \\
Gender (female/male) & $7 / 28$ & $6 / 22$ \\
Hand (right/left) & $20 / 15$ & $18 / 10$ \\
Foucher (zone 2/zone 3) & $8 / 27$ & $10 / 18$ \\
\hline
\end{tabular}

Table 2. The comparison of the group's results

\begin{tabular}{lcc}
\hline & Replantation group (n=35) & Reposition flap group (n=28) \\
\hline Weber static test $(\mathrm{mm})$ [mean (range)] & $4.5(2-7)$ & $5.8(2-9)$ \\
Weber dynamic test $(\mathrm{mm})(\mathrm{mean})$ & 4.1 & 4.7 \\
2-point discrimination test $(\mathrm{mm})$ [mean (range)] & $3.10(1.65-4.09)$ & $3.42(1.68-4.13)$ \\
Self-satisfaction (I-I0) & 8.5 & 7.1 \\
Cold intolerance (\%) & $83 \%$ & $83 \%$ \\
Neuroma & 3 & 1 \\
\hline
\end{tabular}

with a hook nail and 3 patients with a minimal increase in longitudinal curvature were observed. Movements of proximal interphalangeal and distal interphalangeal joints were not restricted. Fingertip sensation was measured as 4.5 (range, 2-7) $\mathrm{mm}$ in Weber static test and an average of $4.5 \mathrm{~mm}$ in Weber dynamic test. Average value in 2-point discrimination test was 3.10 (range, I.654.09) mm. Neuroma formation was observed in 3 patients. In $83 \%$ of the patients, varying degrees of cold intolerance were observed.

Wound dehiscence was observed at the lateral sides of the flaps in 2 patients who underwent reposition procedures. These wound dehiscences were managed with dressings for a certain period and then left to secondary healing. The length of the patients' fingers was an average of I.4 (range, 0-10) $\mathrm{mm}$ longer when compared with the corresponding finger of the other hand. Two patients had clubbed nails. Furthermore, flexion contracture of the DIP joint was detected in 6 patients. In the short-term, restriction in the movement of PIP joint was observed, whereas in the long-term, flexion contracture of the PIP joint was observed in 6 patients. These contractures were corrected with Z-plasties. Weber static and dynamic test results were 5.8 (range, 2-9) $\mathrm{mm}$ and 4.7 $\mathrm{mm}$, respectively. Average measurement for 2-point discrimination test was 3.42 (range, I.68-4.13) mm. Neuroma was detected in I patient. In $87 \%$ of the patients, varying degrees of cold intolerance were detected.

In patients who underwent replantation or flap reposition procedures, if images of the fingers were scored between I and 10 points, average scores were 8.5 and 7.1 points, respectively.

Intergroup comparisons are summarized in Tables I and 2.

\section{Patient Presentations}

Patient I: A 36-year-old woman had a crush injury of her left index finger as a result of a work accident; the fingertip was amputated. Reposition flap was performed for the amputated finger. Flap viability was good and the length of finger was preserved at the postoperative $10^{\text {th }}$ month appearances of the finger (Fig. 2).

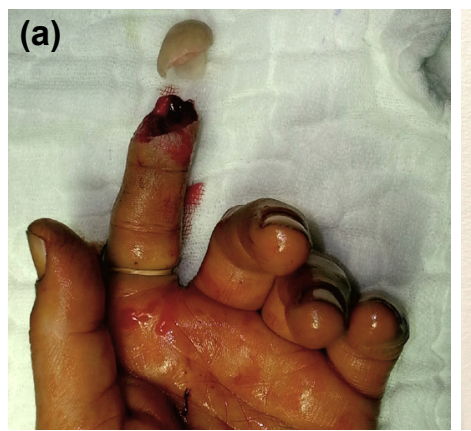

(b)

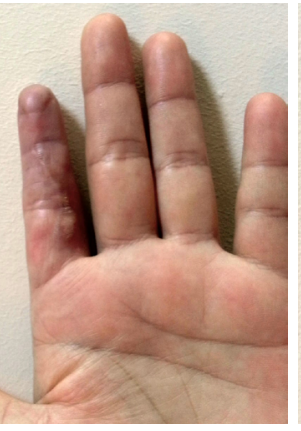

(c)

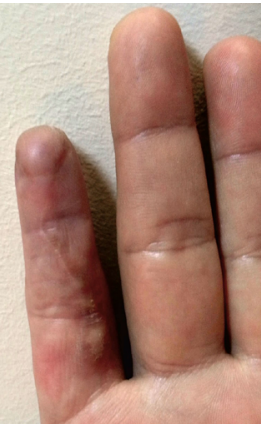

(d)

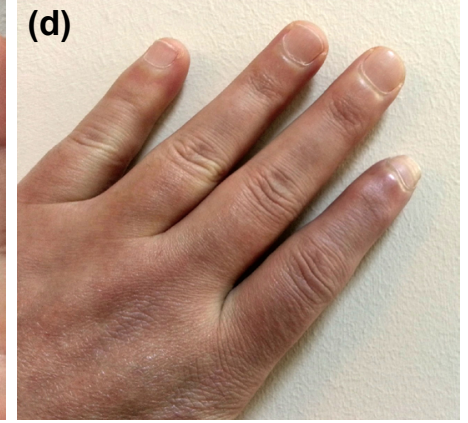

Figure 2. (a) Crush injury of the left index finger. (b-d) Postoperative result at the $8^{\text {th }}$ month. 

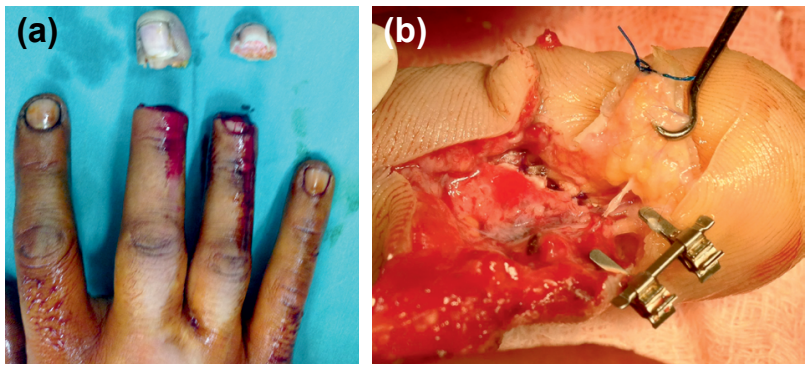

(c)

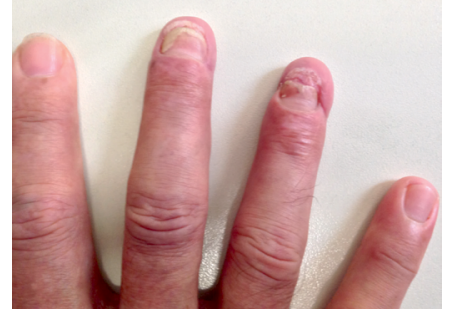

(d)

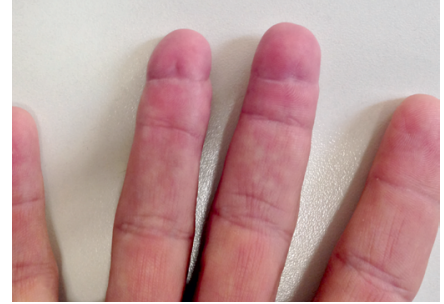

Figure 3. (a) Clean-cut injury of the patient's right middle and ring fingers. (b) Intra-operative photograph showing palmar vein anastomoses. (c,d) Postoperative good aesthetic results at the $15^{\text {th }}$ month.

Patient 2: A 37-year-old man had a clean-cut injury of his left middle and ring fingers as a result of a work accident; the fingertip was amputated. Replantation was performed to the amputated middle and ring fingers. Palmar vein anastomoses was performed and all replantations were successful. The length of fingers was preserved at the postoperative $15^{\text {th }}$ month (Fig. 3).

\section{DISCUSSION}

Sophisticated microsurgery instruments and techniques enable anastomosis of smaller caliber vessels. Anastomosis of such smaller sized vessels has increased the success rate of replantation of fingertip amputations. Therefore, during fingertip amputations, if the amputated segment is in a good condition and is preserved very well during transportation, then for excellent esthetical and functional results, replantation is the gold standard intervention. ${ }^{[6]}$ Though success rates of replantation range between $80 \%$ and $90 \%,{ }^{[7-9]}$ depending on the amputed segment, replantation cannot be performed every time. If replantation is not performed, the patient is left to secondary healing, and this results in the patient taking a long time to return to his/her routine daily life and appearance of the fingertip may not be satisfactory in aesthetic and functional aspects. ${ }^{[10]}$ As a consequence of secondary healing or use of local flaps, the affected finger shortens, and not only its grip strength decreases but also there is a decrease in motor activity while holding small objects. ${ }^{\left[{ }^{\prime I}\right]}$ In patients where replantation cannot be performed, Mantero described flap reposition procedure in 1975 to avoid the shortening of the affected finger. ${ }^{[12]}$ Mantero used cross-finger flap technique with a success rate of approximately $75 \%$. Because Mantero's surgical procedure is multi-staged, Foucher et al. ${ }^{[5]}$ described his single-stage procedure in 1995. They reported that the reposition flap procedure should be used especially in crush injuries with fingertip amputations where success rates are relatively low, time to return to daily life activities is prolonged, and higher operative costs are incurred by secondary interventions to get rid of the effects of failed transplantation procedures. Conversely, varying success rates have been reported for the use of reposition procedures. As a result of studies performed by Dubert et al., ${ }^{[13]}$ clubbed nails were observed in almost all patients. In our series, in all patients, non-dominant homodigital flap was used at a single session and all reposition flap procedures were successful apart from 2 patients with wound site dehiscence. A significant intergroup difference was not found with respect to finger length. During the follow-up period, 2 patients with clubbed nails were observed among patients with reposition flaps. In our replantation series, I patient of hook nail was detected. In our reposition series, during the short-term observation period, 3 patients had nail dystrophy and I patient had a short nail problem. However, these problems disappeared in the long-term. As demonstrated in cadaver studies, we believe that blood flow in nail is supplied from distal phalanx. During the procedure, fixation of distal phalanx on amputated part monocortically and overlay its bone with flap will result in improvement in healing, decrease of resorption on distal phalanx bone and prevention of nail. ${ }^{[14]}$

One of the most important postoperative problems of fingertip amputations is fingertip numbness, which can be resolved with the use of volar or lateral V-Y advancement flaps. As these flaps cannot be designed for large defects and they cannot be extended beyond the distal interphalangeal joint, they have limited indications of use. ${ }^{[15]}$ Reposition flap has some advantages such as excellent recovery of fingertip sensory functions with its soft tissue support, ability to cover large defects and a larger rotation arch than other local flaps. ${ }^{[16]}$ In some studies, no significant difference has been reported at the end of the first postoperative year in patients who had or had not undergone Tamai type I distal finger replantations. ${ }^{[17]}$ However, in some other studies, in patients where nerve repair is not feasible after Tamai type I injuries, similar outcomes have been reported after the repair of one or two terminal branches of the nerve. ${ }^{[2]}$ Before repositioning the flap, as described in the literature, coaptation of the nerve of the flap graft harvested from an appropriate site distal to the other digital nerve of the finger was performed. ${ }^{[18]}$ During our postoperative follow-ups, we did not find a significant difference between patients who underwent reposition flap procedures and replantation with respect to fingertip sensory recovery. Besides, two-point discrimination measurements were found to be similar to the outcomes of some studies. ${ }^{[18,19]}$ Another advantage of nerve repair is to prevent neuroma formation on the nerve terminal to be exposed and then minimize any pain, which will decrease the quality of life. 
When compared to other fingertip reconstructions (i.e., Thenar or cross-finger flap), reposition flap procedures can be used in medical practice in that it is a single-stage method without disadvantages of other methods, such as joint stiffness, restricted range of motion of the joint, and requirement of more than one session of surgery. ${ }^{[20]}$ Potential complications may be related to the flap or composite graft. Providing a good blood supply support may eliminate complications of composite grafts. To prevent the development of restricted extension of the fingertip, postoperative long-term immobilization should be avoided and limited dissection of the distal segment should be performed. ${ }^{[3]}$

However, postoperative problems related to PIP joint due to elevation of reverse homodigital flap and articulopathies of DIP joint associated with reposition of the flap can be observed. Even if the flap is dissected perfectly, because of geometric configuration of the flap, primary and secondary contractions can be observed in the long-term due to primary closure and after its repair with a graft. As a consequence, restricted flexion and extension of the fingertips can be observed. To avoid restricted flexion or extension, rehabilitation should be initiated at an early stage after healing of the flap and in patients of need, it should be prolonged. Contractures formed can be opened with Z-plasties. In our series, we performed Z-plasties in 6 patients and they received an average of 29.4 (range, 28-33) sessions of rehabilitation.

Reposition procedure is less expensive and simple without requiring any special surgical equipment. Microsurgical methods are relatively more costly and require long-term immobilization. ${ }^{[21]}$

\section{Conclusion}

Despite its technical challenges, reposition flap repair can be a good cost-effective alternative to other fingertip repair methods in appropriately selected patients who are not amenable to microsurgery. It preserves the length and sensory functions of fingertips and enables patients to return to their daily life as soon as possible.

Conflict of interest: None declared.

\section{REFERENCES}

1. Allen MJ. Conservative management of finger tip injuries in adults. Hand 1980;12:257-65. [CrossRef]

2. Yamano Y. Replantation of the amputated distal part of the fingers. J Hand Surg Am 1985;10:211-8. [CrossRef]
3. Braga-Silva J, Jaeger M. Repositioning and flap placement in fingertip injuries. Ann Plast Surg 2001;47:60-3. [CrossRef]

4. Robert N, Chassat R, Couturier C, Delpit X, Masmejean E."Repositionflap": A Therapeutic alternative in fingertips amputations. Ann Chir Plast Esthet 2015;60:299-304. [CrossRef]

5. Foucher G, Norris RW. Distal and very distal digital replantations. Br J Plast Surg 1992;45:199-203. [CrossRef]

6. Hattori Y, Doi K, Ikeda K, Estrella EP. A retrospective study of functional outcomes after successful replantation versus amputation closure for single fingertip amputations. J Hand Surg Am 2006;31:811-8.

7. Bora A, Ada S, Ozerkan F, Tetik F. Replantations and their functional results: The Turkish experience. Microsurgery 1993;14:97-101. [CrossRef]

8. Cheng GL, Pan DD, Qu ZY, Lin B, Yang ZX, Fang GR, et al. Digital replantation. A ten-year retrospective study. Chin Med J (Engl) 1991;104:96-102.

9. Glas K, Biemer E, Duspiva KP, Werber K, Stock W, Herndl E. Longterm follow-up results of 97 finger replantations. Arch Orthop Trauma Surg 1982;100:95-8. [CrossRef]

10. Elliot D, Sood MK, Flemming AFS, Swain B. A comparison of replantation and terminalization after distal finger amputation.J Hand Surg $[\mathrm{Br}]$ 1997;4:523-9. [CrossRef]

11. Söderberg T, Nyström A, Hallmans G, Hultén J. Treatment of fingertip amputations with bone exposure. A comparative study between surgical and conservative treatment methods. Scand J Plast Reconstr Surg 1983;17:147-52. [CrossRef]

12. Mantero R, Bertolotti P. Reimplantation of the finger tips using a crossfinger technique [Article in French]. Ann Chir 1975;29:1019-23.

13. Dubert T, Houimli S, Valenti P, Dinh A. Very distal finger amputations: replantation or "reposition-flap" repair? J Hand Surg Br 1997;22:353-8.

14. Kumar VP, Satku K. Treatment and prevention of "hook nail" deformity with anatomic correlation. J Hand Surg Am 1993;18:617-20. [CrossRef]

15. Ozaksar K, Toros T, Sügün TS, Bal E, Ademoğlu Y, Kaplan I. Reconstruction of finger pulp defects using homodigital dorsal middle phalangeal neurovascular advancement flap. J Hand Surg Eur 2010;35:1259. [CrossRef]

16. Chen C, Tang P, Zhang X. Sensory reconstruction of a finger pulp defect using a dorsal homodigital island flap. Plast Reconstr Surg 2012;130:1077-86. [CrossRef]

17. Hirase Y. Salvage of fingertip amputated at nail level: new surgical principles and treatments. Ann Plast Surg 1997;38:151-7. [CrossRef]

18. Yazar M, Aydın A, Kurt Yazar S, Başaran K, Güven E. Sensory recovery of the reverse homodigital island flap in fingertip reconstruction: a review of 66 cases. Acta Orthop Traumatol Turc 2010;44:345-51. [CrossRef]

19. Karamese M, Akatekin A, Abac M, Koplay TG, Tosun Z. Fingertip Reconstruction with reverse adipofascial homodigital flap. Ann Plast Surg 2015;75:158-62. [CrossRef]

20. Vuppalapati G, Oberlin C, Balakrishnan G. "Distally based dorsal hand flaps": clinical experience, cadaveric studies and an update. Br J Plast Surg 2004;57:653-67. [CrossRef]

21. Netscher DT, Meade RA. Reconstruction of fingertip amputations with full-thickness perionychial grafts from the retained part and local flaps. Plast Reconstr Surg 1999;104:1705-12. [CrossRef] 
ORİJINAL ÇALIŞMA - ÖZET

\section{Parmak ucu amputasyonlarında repoziyon flebi kullanımı ve replantasyonların uzun dönem sonuçlarının karşılaştırılması \\ Dr. Emin Sir, ${ }^{1}$ Dr. Alper Aksoy, ${ }^{2}$ Dr. Meliha Kasapoglu Aksoy ${ }^{3}$}

${ }^{1}$ Serbest Hekim, Plastik, Rekonstüktif ve Estetik Cerrahi Bölümü, İzmir

${ }^{2}$ Acıbadem Konur Cerrahi Merkezi, Plastik, Rekonstüktif ve Estetik Cerrahi Bölümü, Bursa

${ }^{3}$ Sağlık Bilimleri Üniversitesi Bursa Yüksek İhtisas Eğitim ve Araştırma Hastanesi, Fiziksel Tıp ve Rehabilitasyon Kliniği, Bursa

AMAÇ: Parmak ucu amputasyonlarında replantasyon altın standarttır. Repozisyon flebi, replantasyonun uygulanamadı̆ı durumlarda parmak uzunluğunu, tırnak kompleksini ve parmak ucu duyusunu korumak amacıyla yapılan, tırnak-kemik kompleksinin serbest greft olarak kullanılması ve flep ile örtülmesi esasına dayanan bir yöntemdir. Bu çalışmada parmak ucu amputasyonlarında yapılan replantasyonlar ile repozisyon flebi uygulanan hastalarının uzun dönem sonuçlarının değerlendirilmesini karşılaştırılması amaçlanmıştır.

GEREÇ VE YÖNTEM: Çalışmaya 2., 3. ve 4. parmakta Foucher sınıflamasına göre zone 2 ve zone 3 parmak ucu ampütasyonu nedeniyle başvuran ve replantasyon yapılmıs 35 hasta, repozisyon flebi uygulanmış 28 hasta dahil edildi. Bütün hastalar ortalama I3 ay (9-23 ay) takip edildi. Bütün hastalar statik ve dinamik iki nokta testi, Semmes-Weinstein monofilaman testi, soğuk intoleransı ve verici saha nöroma gelişimi açısından değerlendirildi. BULGULAR: Replantasyon yapılan beş hastada işlem başarısız oldu. Bu hastaların hepsinde nekrotik dokular uzaklaştırıldıktan sonra lokal flep ile onarım yapıldı. Repozisyon flebi uygulanan iki hastanın flep kenarlarında ayrılma oldu ve pansuman ile takip sonrası sekonder iyileşme gözlendi. TARTIŞMA: Repozisyon flebi mikrocerrahi uygulanamayan durumlarda ve uygun seçilmiş hastalarda, parmak ucu uzunluğunu ve duyusunu koruyan, hastanın gündelik yaşamına bir an önce dönmesini sağlayan bir yöntemdir ve parmak ucu onarımlarında diğer yöntemlere iyi bir alternatif olabilir. Anahtar sözcükler: Amputasyon; parmak ucu; replantasyon; repozisyon flebi.

Ulus Travma Acil Cerrahi Derg 2018;24(5):462-467 doi: 10.5505/tjtes.2018.67217 